\title{
The Role of Bye-Bye Plastic Bags in Realizing Bali Provincial Government Policy Regarding the Restriction of Plastic Bags in 2013-2018
}

\author{
Gita Permata Lestari ${ }^{1}$ \\ Department of Governance Science of Sultan Ageng Tirtayasa \\ University \\ gitaprmt129@gmail.com
}

\section{Tasya Amalia Fitri²}

Department of Governance Science of Sultan Ageng Tirtayasa University

tasyaamalia.fitri2000@gmail.com

\section{Dian Hikmawan ${ }^{3}$}

Department of Governance Science of Sultan Ageng Tirtayasa University

dian.hikmawan@untirta.ac.id
E-ISSN (2721-0642)

Recieved:

June 252020

Revised:

March 352021

Accepted:

April 22021

Doi Number

https://doi.org/10.37950/ijd.v3i1.60

\begin{abstract}
:
Bye Bye Plastic Bags is an environmental movement that emerged due to the unrest of two young people named Isabel Wijsen and Melati Wijsen regarding the problem of using plastic on the island of Bali because plastic waste on the island of Bali turned out to be found in rice fields and beaches which caused clogged gutters and filled the river. This is a problem in the reality of the environment in Bali should be a concern for local governments and communities. Therefore in this study an analysis will be made on the role of Bye Bye Plastic Bags in realizing the policy of the Provincial Government of Bali in limiting plastic bags in 2013-2018. Theories used in this study are environmental political actors, new social movements and environmental movements and non-government organizations. The method used in this research is a qualitative descriptive approach to explain the journey of Bye Bye Plastic Bags in carrying out its programs and activities so as to realize the policies of the Bali government. The results of the analysis show that the successful activities carried out by Bye Bye Plastic Bags in 2013-2018 in realizing the policy of the Provincial Government of Bali regarding the limitation of plastic bags, namely Spreading Awareness and Education, Creating Policy and Regulation with Government, Showing Solution, and Growing the Movement.
\end{abstract}

Keywords: new social movement, environmental movement, environmental politics. 


\section{Abstrak}

Bye Bye Plastic Bags merupakan gerakan lingkungan yang muncul akibat keresahan dua anak muda bernama Isabel Wijsen dan Melati Wijsen terkait masalah penggunaan plastik di pulau Bali karena sampah plastik di pulau Bali ternyata terdapat pada beras. sawah dan pantai yang menyebabkan selokan tersumbat dan memenuhi sungai. Hal ini menjadi masalah dalam realitas lingkungan hidup di Bali yang harus menjadi perhatian pemerintah daerah dan masyarakat. Oleh karena itu dalam penelitian ini akan dilakukan analisis tentang peran Kantong Plastik Bye Bye dalam mewujudkan kebijakan Pemerintah Provinsi Bali dalam pembatasan kantong plastik tahun 2013-2018. Teori yang digunakan dalam penelitian ini adalah para aktor politik lingkungan, gerakan sosial baru dan gerakan lingkungan serta lembaga swadaya masyarakat. Metode yang digunakan dalam penelitian ini adalah pendekatan deskriptif kualitatif untuk menjelaskan perjalanan Kantong Plastik Bye Bye dalam menjalankan program dan kegiatannya guna mewujudkan kebijakan Pemerintah Bali. Hasil analisis menunjukkan bahwa keberhasilan kegiatan yang dilakukan Kantong Plastik Bye Bye tahun 2013-2018 dalam mewujudkan kebijakan Pemerintah Provinsi Bali mengenai pembatasan kantong plastik yaitu Penyebaran Kesadaran dan Edukasi, Membuat Kebijakan dan Regulasi dengan Pemerintah, Menunjukkan Solusi, dan Menumbuhkan Gerakan.

Keywords: gerakan sosial baru, gerakan lingkungan, politik lingkungan.

\section{Introduction}

The problem of plastic waste in Indonesia is still a major polemic and is difficult to handle. Every day Indonesian people often use plastic bags. The number of uses of plastic bags causes plastic waste to increase. Plastic waste in Indonesia ranks second highest at $16 \%$ after organic waste at $57 \%$ (KLHK, 2018). Based on data from KLHK, Indonesia produces 175,000 tons of plastic waste every day and about 64 million tons of plastic waste annually. Indonesia is the second highest producer of plastic waste in the world (Fajrian, 2019). The high waste generation is also triggered by the rapid growth of Indonesia's urban population and increasing activity and consumption of urban communities (KLHK, 2018). However, KLHK states that approximately $72 \%$ of Indonesian people do not care about plastic waste (Din, 2019), causing the generation of plastic waste to continue to increase.

Bali is one of the provinces in Indonesia with a population of 2019 reaching 4.36 million people, equivalent to $1.63 \%$ of the total population in Indonesia. Bali is one of the tourist destinations with the most local tourists and local tourists visiting. With all the natural beauty that exists in Bali, environmental conditions on the island of Bali related to plastic waste is quite alarming. The tourism sector is one of the causes of the high level of plastic waste on the island of Bali due to the large number of local and foreign tourists who come and go, causing a high level of activity and public 
consumption. The results of research conducted by the Bali Partnership in 2019 showed that plastic waste in Bali is 303,000 tons annually or $19.6 \%$ of the total waste in Bali every year.

Of the many plastic waste that is produced from the island of Bali each year, as many as 33 thousand tons of plastic waste is discharged into the sea (Rosidin, 2019). The emergency condition of the plastic waste needs to be dealt with seeing that Bali is a center of tourism and has always been a global concern. These problems not only disrupt the tourism sector but are also dangerous for the people and ecosystems in the sea. Plastic waste deposits can cause unpleasant odors, cause flooding due to blocked drainage channels and can increase the high mortality rate of animals. Environmental sustainability needs to be maintained so as not to pose a threat to the living creatures that inhabit it. The problem of plastic waste on the island of Bali must be the center of attention not only for the government but also for the community. With the high sense of indifference of the people of Indonesia to plastic waste, causing problems such as plastic waste in Indonesia never stops. Therefore, we need a high level of environmental awareness from the Balinese people to create a Balinese environment that is friendly to plastic bags.

The sense of environmental care was present in two young people who came from Bali Island named Melati Wijsen and Isabel Wijsen. They feel that plastic waste is a very serious problem and needs to be dealt with immediately because plastic waste on the island of Bali can actually be found in rice fields, beaches, causing clogged gutters and filling rivers. They chose plastic waste as the main issue because plastic is an object that is used and thrown away every day. Therefore, Melati and Isabel then took the initiative to create a campaign about environmental awareness and reducing the use of plastic bags to their peers at their school. The campaign carried out by Melati and Isabel then grew bigger and was named as Bye-Bye Plastic Bags. Melati and Isabel strive to create a plastic-free Bali island as implemented in several countries that are classified as successful in reducing plastic waste such as policies to limit the use of plastic products through taxes imposed in Denmark as well as policies to prohibit the production, distribution, and consumption of certain types plastic bags applied in Rwanda (Pramatatya, 2017).

The campaign began in 2013 when Melati was 12 years old and Isabel was 10 years old. They proposed the idea of Bye Bye Plastic Bags at the GIN (Global Initiative Network) Youth Conference in Bali. The Bye Bye Plastic Bags movement campaigned by Isabel and Melati then developed into an NGOs (Non-Governmental Organization) that focuses on environmental issues. Bye Bye Plastic Bags hopes that Bali can become an area free from plastic bags. However, this cannot be done if only through the bottom up system, but also needs to be matched with the top down system. The environmental awareness of the community apparently must be accompanied by regulations issued by the local government so that Bali free of plastic bags can be realized immediately. Because previously there were no regulations governing the use or restrictions of plastic bags either in the Province of Bali. Therefore, Bye-Bye Plastic Bags are trying to get the 
government to glance at what they are doing in this movement. With this there is hope that the government will pay attention to the continuing impact of this movement which aims to make Bali free from plastic bags.

Activities carried out by Bye-Bye Plastic Bags can be classified into 4 types of activities namely Spreading Awareness and Education, Creating Policy and Regulation with Government, Showing Solution, and Growing the Movement. Research on the role of the community or NGOs in the management of plastic waste was also carried out by Hidayatullah Kurniadi and Mohammad Hizasaling in their research entitled "Strategy of the Plastic Bags Diet Campaign by GDIKP in Indonesia". This study discusses the campaign strategy used by the Indonesian Movement for Plastic Bags Diet (GDIKP) as an effort to reduce the use of plastic bags in Indonesia by using a strategic approach that contains 3 components namely Regulation, Education and Facilitation. The strategic targets undertaken by GDKIP are the government, the community and retail businesses, so that the use of plastic bags can be reduced and replaced with other bags made of reusable materials (Kurniadi \& Hizasalasi, 2017).

Subsequent research that discusses the role of environmental actors was carried out by Firohatin Ronasifah, Nurul Umi Ati and Hayat in his research entitled "The Role of Non-Governmental Organizations (NGOs) in the Horizon of Justice in Environmental Empowerment (Study of the Waste Care Movement in Paciran Village, Paciran District, Lamongan District)". This study discusses the role of the NGOs Horizon Justice, the driving factors and inhibitors of environmental empowerment in Paciran Village. The Justice Horizon NGOs was very instrumental in realizing environmental empowerment in Paciran Village by forming a work program called the Waste Care Movement which then affected employment opportunities for people living in the Paciran Village area (Ronasifah et al., 2019). Research by the authors is a followup study of studies that have been done previously about waste, especially plastic waste, but the research that the authors did uses different research objects. The object of the authors research is an NGOs in Bali, Bye-Bye Plastic Bags. Based on the background above, the authors will focus on writing about the role of the Bye-Bye Plastic Bags movement in realizing the policy of the Provincial Government of Bali regarding the restrictions on plastic bags in 2013-2018.

\section{Theoritical Framework}

\section{Environmental Political Actor}

Environmental politics according to Paterson is an approach formed between a combination of environmental problems and economic politics to represent a dynamic change of tension between the environment and humans and between diverse groups in society on a scale from local individuals to transnational as a whole (Hidayat, 2011). According to Herman Hidayat, actors in environmental politics are divided into two namely (Wahyudin, 2018):

a. The Role of a Direct Actor 
Direct actors are actors where the State that embodies development is also accompanied by environmental sustainability and as the most influential and responsible actor for environmental damage due to policy making, executors, implementers, supervisors and managers until the evaluation is carried out by the state.

b. The Role of Indirect Actors

Indirect actors are actors consisting of academic and research institutions, international finance (World Bank, International Monetary Fund, Asian Development Bank), local, national and international NGOs or NGOs.

\section{New Social Movements and Environmental Movements}

Quoted from Sari and Siahainenia (Sari \& Siahainenia, 2015), according to Achwan, a new social movement moves in relation to symbolic and cultural issues and identity, then pays more attention to life politics so that its membership is open without looking at class social, political and religious. New social movements can be interpreted as an association of actors as well as groups who mobilize themselves to be with one another fighting for the democratization of everyday life in which they contain certain values such as:

1. A strong connection but the form of interaction is informal or unstructured

2. The existence of equality of confidence and solidarity

3. The existence of joint action, bringing issues that constitute social conflict

4. Actions that are sustainable but not routinely as is known in the organization

According to Jenkins, the environmental social movement is a triangulation of social and political movements aimed at preserving and improving the natural environment through public education, advocating for better lifestyle choices, improvement in community planning (improved community planning), improvement financial investment and government regulation (Rochwulaningsih, 2017). The environmental movement was born out of humanity's anxiety about the increasingly worrisome condition of the environment (Hikmawan \& Hidayat, 2016). In the environmental movement there are actors who move through specialized organizations that are established to try to improve their environmental conditions and sometimes even crossnational borders which are called Organized Environmentalists (Nugroho, 2017). In this study, the organization in question is Bye-Bye Plastic Bags.

\section{Non-Profit dan Non-Government Organization}

A non-profit organization is an organization whose purpose is to support an issue to make the public interested in issues of social problems without any intention of making a profit. Non-profit organizations were established with the aim of realizing changes in individuals or communities, these non-profit organizations also make human resources a valuable source of wealth because basically the activities or programs that these organizations do are from humans, by humans and for humans (Komang, 2008).

Quoted from Wulan and Muktiali (Wulan \& Muktiali, 2013) a non-government organization is an organization established individually or in a group that engages in 
community empowerment and development, an organization is said to be a nongovernment organization with several characteristics, such as:

a) Organizations that are not part of the government or country

b) In carrying out activities, campaigns or programs are not based on profit seeking

c) Activities or campaigns carried out are in the interest of the general public not only for the benefit of the organization itself

In describing the explanation above, the classification of the Bye Bye Plastic Bags organization is a type of non-profit and non-government organization.

\section{Research Methodology}

In this study using a qualitative approach, because the problem that will be discussed here is an analysis that deals with humans and relies on observation. Moleong said that qualitative research is research that intends to understand phenomena about what is experienced by research subjects such as behavior, perspective, motivation, action holistically and by means of descriptions in the form of words and languages, in a special natural context and by utilizing various natural methods (Moleong, 2011). Meanwhile, Sugiyono argues that the qualitative research method is a method based on the philosophy of post-positivism, then to examine natural objects where the researcher is the key instrument, data collection techniques are carried out by means of triangulation (combined), data analysis is inductive or qualitative and research results more emphasis on meaning than generalization (Sugiyono, 2011).

The method that will be used in this research is descriptive method. Descriptive method is a method that examines the status of human groups, a subject, a set of conditions, a system of thought or class of events in the present, then the purpose of this descriptive research is to make a systematic description or picture and the relationship between the phenomenon or problem being investigated (Nazir, 2011). The use of descriptive method in this study because this research examines the Bye Bye Plastic Bags which is a group of people in the form of a movement and then becomes an NGOs.

In this study, the key instrument is the researcher himself, then the data collection technique becomes an important support in the main because the purpose of this study is to obtain truth-based data without any manipulation. Therefore, this research uses several techniques to gather data, including Interview is a conversation with a specific purpose that the conversation was conducted with two parties, namely the interviewer who asked the question and the interviewer who provided the answer to the question (Moleong, 2010). The interview was addressed to the Team Leader of the Volunteer Bye-Bye Plastic Bags, named Sandrio Eldio.

Danial and Warsiah said that the literature study is research conducted by researchers by collecting a number of books, magazines or other sources of literature that are deemed to be problematic and research objectives (Danial dan Wasriah, 2009). The writers use this technique in this research in expressing the theories that this 
research use, then the previous studies such as journals and books that are relevant to this research.

This study will use analytical techniques according to Sugiyono where later the data and results of the analysis will be organized in an organized manner. Data analysis is the process of systematically searching and compiling data obtained from interviews, field notes and documentation, by organizing data or compiling into categories in sequence, describing into units, then synthesizing, then composing into patterns, selecting which are important and which will be studied in the data before being analyzed and making conclusions so that they are easily understood by themselves or others or readers (readers) (Sugiyono, 2009).

\section{Result and Discussion}

Bye-Bye Plastic Bags is an organization engaged in environmental awareness in Bali Province. In the beginning, Bye-Bye Plastic Bags was a social movement that was moved by two siblings, Melati Wijsen and Isabel Wijsen in 2013, by implementing this activity to friends in her school environment. After the emergence of awareness from some of her school friends, this activity developed so that it was recognized by the people in their environment. It was the emergence of this awareness that made this activity a social movement engaged in caring for the environment, by taking into account the situation and the issues in Bali. plastic is on the rise in the attention of the entire world. The social movement spearheaded by these siblings gave birth to many volunteers who were willing to help them make a healthier and cleaner environment, not only the surrounding community who were moving but there were some foreign citizens who only visited Bali to join this movement. The rapid development of this movement has made this movement an organization which is now naturally engaged in environmental issues especially plastic bags.

Bye-Bye Plastic Bags then developed into an organization without assistance from the government and without aiming to make a profit in 2018. Can the authors conclude that Bye Bye Plastics Bags are non-profit and non-government organizations because they stand alone with the aim of making people aware of the Balinese and outside Bali to care about the environment by reducing the use of plastic bags. Various activities carried out by Bye-Bye Plastic Bags as an effort to reduce the use of plastic bags on the island of Bali. First, Spreading Awareness and Education through presentations in schools and communities, workshops, making booths at community events and various other campaigns. Bye-Bye Plastic Bags has conducted Spreading Awareness and Education to approximately 16,000 school students in 12 countries in 8 different languages. Bye-Bye Plastic Bags also made the first educational booklet in 2014 which contained the dangers of using plastics that were distributed to 30 schools in Indonesia and also distributed free of charge via PDF which can be accessed by all people.

Second, Showing Solutions which contains several activities including creating a Pilot Village in 2014. Pilot Village is making a sample village without plastic bags, the 
village used as a sample village is Pererenan village in Bali. Bye-Bye Plastic Bags donated alternative bags distributed every Saturday for many years and to date at least once a month so that the Pererenan village does not need to use plastic bags. The next effort is to launch a One Island One Voice campaign where Bye-Bye Plastic Bags rewards plastic bag-free organizations such as restaurants, supermarkets and hotels by giving them stickers and uploading their photos and names on the Bye-Bye Plastic Bags social media. The next activity is to create a Mountain Mama Social Enterprise Project: Making Bags in the Mountains. This project was carried out by means of women in the village of Wanagiri Kauh, Bali making alternative bags using donated clothing materials such as bed linen that had been worn out from hotels etc. The resulting alternative bags will be sold throughout Bali. This was also done to provide women with opportunities to work in the village of Wanagiri Kauh. The last showing solution is River Booms, where Bye Bye Plastic Bags collaborates with the Ocean Recovery Alliance and the Global Alert Project to create river dams in several mouths of the southern Bali river. This river dam will later filter waste that can be carried to the sea or stuck to the coastline.

Third, Growing the Movement. In 2016 Bye-Bye Platic Bags created the first team outside Bali and in 2018 there were 20 teams outside Bali with the same mission to ban the use of plastic bags. Fourth, Creating Policy and Regulation with Government. To achieve a plastic bag-free Bali that cannot be done only with a bottom up, a top down system is needed to realize this. From the results of our interview with the Volunteer Bye-Bye Plastic Bags Team Leader, Sandrio Eldio, said that creating policy and regulation with government began with a hunger strike by Melati and Isabel in order to meet with the Governor of Bali, Mangku Paskita. In the end they were able to meet with the Governor of Bali and discuss the importance of making a policy on limiting plastic bags in Bali. In November 2014, the signing of the collaboration (MoU) with the Governor of Bali was carried out to prevent the Balinese from using plastic bags.

The policy making on limiting plastic bags in Bali through a very long process. After the signing of the MoU in 2014, in May 2015 a Circular Letter was signed by the Governor of Bali, Mangku Paskita. In the Circular, the Province of Bali announced their commitment to make Bali free of plastic bags by 2018.

The first government and stakeholder meeting on the policy to be made was held on 15 May 2017 organized by Bye-Bye Plastic Bags and attended by representatives of the Regent's office, BLH office and several stakeholders from local NGOs and local businesses. This meeting aims to find out the continued news of the local government and discuss ways to further contribute to the actions they take to make Bali free of plastic bags. The first meeting produced a Support Letter that had been designed and signed by the Regent and BLH in Bali, which agreed that many adverse effects resulted from the use of plastic bags.

After the first meeting the second follow-up meeting was held on August 9, 2017 which was again held by Bye-Bye Plastic Bags and attended by the same preacher as the first meeting namely the Regent of Bali, BLH and stakeholders. Bye-Bye Plastic Bags 
gave a presentation on the suggestions they planned to charge the plastic bags starting on January 1, 2018. The second meeting resulted in support of the advice given by the Bye-Bye Plastic Bags but the method for its success is still questionable. So that, the head of BLH, Mr. Surjana suggested to hold a follow-up meeting in September with each regional head again to present their action plans related to the imposition of plastic bag costs and conduct the socialization needed to realize this. The Regents are also required to submit a list of shops that will carry out a trial of charging fees on plastic bags in each region during the trial period in October-December.

The third meeting was held on September 4, 2017 to discuss the regulation of the implementation of paid plastic in Bali's Regencies / Cities. The plan to impose costs on plastic bags in Bali is 5.000 rupiahs for one bag. But Ms. Putu Yupi Wahyundari who is a representative of the Waste Management, B3 Waste and Regional Agency Capacity Development for Environmental Affairs of the Province of Bali said that "If the central government has not yet issued regulations (Ministerial Regulations), then as regional governments we cannot take action to fill 5.000 rupiahs per-disposable plastic bag as proposed by BBPB. We do not have the authority to take this action without the central government issuing a Ministerial Regulation regarding this matter". The third meeting resulted in the government officials present saying that Bali did not have the authority to charge fees on plastic bags. Because Bali is a part of Indonesia that is not federal, the local government of Bali cannot move alone. The regional government must follow the central government regarding the regulation of the imposition of fees on plastic bags and discuss this with the local government as well as the DPRD.

After a long process carried out and passed by Bye-Bye Plastic Bags, the policy regarding the limitation of plastic bags was issued by the Governor of Bali on December 21, 2017. The policy was finally ratified and contained in the Governor of Bali Regulation No. 97 of 2018 concerning Restrictions on Plastic Waste Collection Once Use. Bye-Bye Plastic Bags became a non-governmental organization after going through several challenges on its journey and after the policy issued by the Governor of Bali in 2018. With the initial story not so good, the two leading figures of Bye-Bye Plastic Bags named Melati Wijsen and Isabel Wijsen This experienced a lot of obstacles, for example only obstacles where they are considered only as small children. However, after running a number of programs they were finally able to get the attention of the government of Bali which they gained recognition as an excellent environmental movement for the future. Through some cooperation with the government until the issuance of policies from the government of Bali Province. The policy of the Governor of Bali was explained after several cooperation meetings and circular letters were held.

David Easton said that public policy is the power to allocate values to society evenly or contain government authority (policy) that covers the overall social life of the community (Widianti \& Rahman, 2017). Public policy is usually in the implementation of policies interpreted by Van Horns (Widianti \& Rahman, 2017) as actions taken by individuals or groups, government or private designed to achieve the goals set in policy decisions, there are 6 aspects that affect public policy performance these, namely: 
1. Size and objectives of public policy

2. Resources

3. Characteristics of implementing agencies

4. The attitude or tendency of the implementers

5. Communication between organizations and implementing activities

6. Social, economic and political environment

The form of public policy made by the government in this study is Governor Regulation Number 97 Year 2018 Regarding the Limitation of Disposable Plastic Waste Disposal in Bali Province. Governor Regulation is a regulation or policy that is designed or made by the Governor or which has the authority to be implemented to the people in the area.

The output of the Bye-Bye Plastic Bags movement is the policy of the government to deal with the main problems that this movement raises as a reality that must be considered. From 2013 the journey of the Bye-Bye Plastic Bags movement was categorized as a new social movement in which social and political movements aimed at preserving and improving the natural environment through public education, advocating for better lifestyle choices, improvements in community planning and government regulation. in 2015 this movement experienced turmoil which was considered high because those who began to realize and follow the Bye-Bye Plastic Bags movement were increasing and not only the local community but many foreign citizens who participated.

The explanation that has been explained above if the writer uses the analysis of environmental politics according to Paterson is an approach that combines environmental problems with politics or economics to represent a dynamic change of attention between the environment and humans and between various groups within the community on a scale from local individuals to transnational and international as a whole (Hidayat, 2011). It is proven through that in this journal the form is an environmental problem, namely the amount of plastic bags waste that pollutes the surrounding environment which then produces a form of government policy regarding the reduction in the use of plastic bags. Of course, assisted with the role of environmental political actors in the form of indirect actors consisting of local, national and international NGOs or NGOs. In this journal, the political actor is the Bye-Bye Plastic Bags which is a non-governmental organization that stands independently without financial assistance from the government and part of the government or country.

\section{Conclusion}

Based on the discussion of the research it can be concluded that the role of ByeBye Plastic Bags in environmental politics is categorized as an indirect actor, that is, a non-governmental organization. Various efforts have been made by Bye-Bye Plastic Bags to make the Balinese people aware of the dangers of using plastic bags such as by conducting Spreading Awareness and Education, Showing Solutions, Growing the 
Movement and Creating Policy and Regulation with Government. The output of ByeBye Plastic Bags is to make the public and the government of Bali more aware of the large amount of plastic bag waste that pollutes the environment can have a negative impact on the future. In addition, the objectives of the Bye-Bye Plastic Bags from the beginning of the formation of the environmental movement in 2013 to becoming a nongovernmental organization in 2018 produced results, namely the government policy issued by the Governor of Bali Province in the Governor of Bali Number 97 of 2018 concerning Restrictions on Plastic Waste Generation Disposable. The role of Bye-Bye Plastic Bags can be said to be successful because it impacts the surrounding community and the government, even foreign citizens.

The advice that the authors can give in this research is that Bye-Bye Plastic Bags can continues to grow so that they can become a reference to be aware of the environment and reduce excessive plastic bags waste for other regions in Indonesia and even this country itself. Then for the government of Bali itself, it is expected that with the ratification of the Bali Governor's regulation regarding the restrictions on the use of plastic bags in 2018 can be implemented and adhered to by the community.

\section{About Authors}

Gita Permata Lestari is a student at Government Department Universitas Sultan Ageng Tirtayasa, She is interest in Environmetal Politics

Tasya Amalia Fitri is a student at Government Department Universitas Sultan Ageng Tirtayasa, She is interest in Environmetal Politics

M Dian Hikmawan is a lecturer at Government Department Universitas Sultan Ageng Tirtayasa, his research focus on citizenship, human rights and democracy

\section{Acknowledgment}

The authors thanks to all the colleagues who make this research proper to be published.

\section{Reference}

Danial dan Wasriah. (2009). Metode Penulisan Karya Ilmiah. Laboratorium Pendidikan Kewarganegaraan UPI.

Din. (2019). KLHK: 72 Persen Masyarakat Tak Peduli dengan Sampah Plastik. CNN Indonesia.

Fajrian. (2019). Infografis : Sampah Plastik Indonesia dalam Angka. CNN Indonesia.

Hidayat, H. (2011). Politik Lingkungan: Pengelolaan Hutan Masa Orde Baru dan Reformasi. Yayasan Pustaka Obor Indonesia.

Hikmawan, M. D., \& Hidayat, R. (2016). Depoliticisation of Public Issue : Low Degree of Government' S Democratic Legitimacy. Journal of Governance, 1(1), 23-37.

https:// doi.org/http://dx.doi.org/10.31506/jog.v1i1.1311

KLHK. (2018). Deklarasi Kendalikan Sampah Plastik Industri. Www.Ppkl.Menlhk.Go.Id. 
Komang, A. (2008). Perilaku Keorganisasian. Graha Ilmu.

Kurniadi, H., \& Hizasalasi, M. (2017). Strategi Kampanye Diet Kantong Plastik. 2th Celscitech-UMRI 2017, 2, 73-78.

Moleong, L. J. (2010). Metodologi Penelitian Kualitatif. Remaja Rosda Karya.

Moleong, L. J. (2011). Metode Penelitian Kualitatif Edisi Revisi. PT. Remaja Rosdakarya.

Nazir, M. (2011). Metode Penelitian. Ghalia Indonesia.

Nugroho, A. (2017). Geliat Organisasi Pemuda Lingkungan (Opl) Dalam Ranah Gerakan Lingkungan Di Yogyakarta. Jurnal Sosiologi Agama, 9(1), 190. https://doi.org/10.14421/jsa.2015.091-07

Pramatatya, Y. (2017). Upaya Bye Bye Plastic Bags dalam Mencapai Bali Bebas Tas Plastik (2013-Mei 2017). Skripsi, 451.

Rochwulaningsih, Y. (2017). Dinamika Gerakan Lingkungan dan Global Environmental Governance. Jurnal Sejarah Citra Lekha, 2(2), 151. https:// doi.org/10.14710/jscl.v2i2.16188

Ronasifah, F., Publik, J. A., Admiministrasi, F. I., Malang, U. I., Mt, J., Malang, H., Unisma, L., Mt, J., \& Malang, H. (2019). PERAN LEMBAGA SWADAYA MASYARAKAT (LSM) CAKRAWALA KEADILAN DALAM PEMBERDAYAAN LINGKUNGAN ( Studi Tentang Gerakan Peduli Sampah Di Desa Paciran Kecamatan Paciran Kabupaten Lamongan ). Jurnal Respon Publik, 13(3), 53-61.

Rosidin, I. (2019). Peneliti : 33 Ribu Ton/Tahun Sampah Plastik Terbuang ke Laut. IDN Times Bali.

Sari, D. K., \& Siahainenia, R. R. (2015). Gerakan Sosial Baru di Ruang Publik Virtual pada Kasus Satinah. Jurnal ILMU KOMUNIKASI, 12(1). https:// doi.org/10.24002/jik.v12i1.446

Sugiyono. (2009). Metode Penelitian Kuantitatif, Kualitatif dan REDD. Alfabeta.

Sugiyono. (2011). Metode Penelitian Kuantitatif, Kualitatif dan REDD. Alfabeta.

Wahyudin, E. A. (2018). Gerakan Sosial Baru Dan Politik Lingkungan (Studi Atas Kontribusi Walhi Terhadap Ruang Terbuka Hijau Di Dki Jakarta 2004-2017). Universitas Islam Negeri Syarif Hidayatullah Jakarta.

Widianti, V., \& Rahman, A. Z. (2017). Implementasi Peraturan Gubernur Provinsi DKI Jakarta Nomor 123 Tahun 2014 Tentang Kepesertaan Dan Pelayanan Jaminan Kesehatan Di DKI Jakarta. Indonesian Journal of Public Policy and Management Review, 6, 431-440.

Wulan, R. M., \& Muktiali, M. (2013). Peran Non Governmental Organization (GIZ dan LSM Bina Swadaya) terhadap Klaster Susu Sapi Perah di Kabupaten Boyolali. Jurnal Wilayah Dan Lingkungan, 1(2), 157. https:/ / doi.org/10.14710/jwl.1.2.157-174 